PRODUCTION

ENGINEERING

ARCHIVES
2016, Vol. 12, No. 3, pp 42-45

ISSN 2353-5156 (print version)

ISSN 2353-7779 (online version)

Article history: Received:15.09.2016 Accepted: 26.09.2016 Online: 30.09 .2016

\title{
Engineering production education in e-learning example in Poland
}

\author{
Joanna Rosak-Szyrocka ${ }^{1}$, Martina Blašková ${ }^{2}$ \\ ${ }^{1}$ Institute of Production Engineering, Czestochowa University of Technology, Poland, asros@op.pl \\ ${ }^{2}$ University of Žilina, Faculty of Management Science and Informatics, martina.blaskova@ fri.uniza.sk
}

\begin{abstract}
It can be observed that the modern world which is subjected to a variety of changes, in particular socio-economic and civilizational ones, known commonly as the so called information revolution creates the need for intense search for new, more effective educational models. All the changes are linked to the formation of network society, information society and knowledge-based economy, which are termed differently in science. The paper discusses research conducted among 698 students of Czestochowa University of Technology and Wroclaw University of Technology in Poland. The aim of the following work is to indicate main problem areas and provide solutions to them.
\end{abstract}

Key words - e-learning, Moodle platform, education.

\section{Introduction}

In current discourses on sustainable development, one can discern two main intellectual cultures: an analytic one focusing on measuring problems and prioritizing measures, (Life Cycle Analysis (LCA), Mass Flow Analysis (MFA), etc.) and a policy/management one, focusing on long term change, change of incentives, and stakeholder management (Transitions/niches, Environmental economy, Cleaner production). Educating a new type of engineer requires a paradigm shift in engineering. The future requires an engineer who combines the usual scientific strengths of engineering with strength in managing change and innovation in order to deliver systems level innovation. Innovation is still promoted as if the world is still almost a barren place to be filled with ingenious products and systems.

The development of the Internet and its applications determined an increase of the role of computerbased instruments in the learning process. This is the reason why educational institutions have an increasing need to use virtual learning environments (VLE), namely an electronic learning platform that accompanies the traditional teaching-learning-assessment process (OPROIU G.C. 2014).

Within only a few years, the use of e-learning has increased rapidly in Poland. Although the advantages and disadvantages of e-learning were discussed in a variety of previous studies, it is crucial to understand why some students are dissatisfied with their elearning practice (MULDER K. F. 2016.).

E-Learning has become an important educational instrument in the new Higher Educational Environment in the digital age which creates student-centered learning and educational skills and offers new more flexible and interesting learning methods.

Education connected with performing tasks using Moodle and other related resources and Internet Tools reveals new unknown areas and opportunities to students. It makes young people realize what the educational usefulness of the network is and how many abilities associated with the efficient use of the Internet (other than entertainment or social) they still have to possess. 
E-learning, until recently known as the future of education, is becoming the present reality. It brings a number of new opportunities (WU J.H., 2008).

\section{New education form in Polish univer- sities}

As a result of the popularization of the Internet, educational technologies have widely developed and, as the educational process is further improving, the Internet users fully benefit from the process, which is adequate to their expectations.Educational and formal training programs are ever more adapted to students' needs, and the instruments used can be accompanied by a wide variety of education related services, by an extended flexibility of the learning directions, a higher complexity of the trainers' role or by an improvement of teamwork. adults' participation in permanent education requires a series of activities to be performed as computer reproduced or simulated representations, supported by various animation methods and techniques, sounds, colours, and graphics (BEDRULE GRIGORUTAM. V., RUSU M. L. 2014).

E-learning is one of knowledge transferring methods and it is increasingly used in Poland in economic education at university level. Enrichment of teaching process offered at the level of academic courses just by creating learning opportunities through the Internet is a noticeable trend also in Polish academic practice.

Distance learning can be defined as a form of education in which interactions between the learner and the teacher do not require the presence of both participants of the education process at the same time in the same place. The development of modern information and communication technologies has contributed to the increasingly common support of teaching by means of computers and the Internet (e-learning).

E-learning is not only connected with studying itself, but also with the competence control (ARDID, 2015).

There are following advantages of e-learning education (PAECHTER, 2010; LIAW, 2007; OTTER, 2013):

- Content standardization.

- Precise control of the learning process and its effects.

- Access to online materials in a given courseat anytime from anyplace.

- Reduced tuition costs (important especially in the case of training a large number of people, e.g. for companies).
- Increased availability of educational services (lack of spatial barriers, which is important e.g. for people with disabilities).

- Making learning process more attractive through the use of multimedia.

- The possibility to learn at one's own pace and at the preferredtime.

- Minimizing students' fear and timidity.

- Implementation of traits such as being systematic and self-reliant among learners.

- Removal of restrictions related to the time and place of study.

- In the case of e-tests: objectivity of evaluation.

- Immediacy of assessment (the grade can be issued immediately after the test).

There also disadvantages of e-learning:

- Lack of the personal contact with the teacher.

- Lack of the direct contact with other learners - the feeling of isolation.

- A high level of self-discipline or self-direct is required.

- The difficulty in an appropriate and individualized motivation of learners.

- The diversity of results depending on learners' computer competence.

- The need to have hardware with suitable parameters.

- Greater amount of time on the tutor's side (preparation of the materials, correspondence with students).

- Vulnerability to technical problems.

- No rules concerning diploma recognition.

- None or very limited opportunities to acquire and improve practical skills, which is crucial within the fields such as medicine or performing arts.

- In the case of e-tests: key evaluation (the final result is assessed, not the line of reasoning).

- Problems with the remote verification of the identity of the students taking e-tests.

\section{Research and their analysis}

A study concerning students' satisfaction with elearning was conducted at the Czestochowa University of Technology. It began in 2013 and refers to a quarterly period. The survey was conducted among 209 university students. As far as the second research is concerned, it was conducted on the Faculty of Chemistry at the Wroclaw University of Technology, and the answers were provided anonymously by 489 surveyed students. Its aim was to determine the degree of of students' satisfaction with the education form which is 
offered by Moodle platform; as well as to improve elearning activities, and to identify which form of activities cause the most problems for the students.

Moodle platform is used as a learning resource, as teaching-learning-assessment means alongside traditional teaching, learning and assessment methods and means.

Respondents had to answer the following questions:

1. How many times did you participate in the eleraning lessons at the Faculty of Management Czestochowa University of Technology?

Once.

More than twice.

Three times and more.

2. Did you take part in the training on how to use

Moodle platform before starting the course?

Yes.

No.

3. Did you get help from teachers in charge of the classes when you encounteredproblems with passing the modules?

Yes.

No.

4. What is your opinion on the future of e-learning at the University?

Nothing will changed.

Approximately $25 \%$ of the classes will be conducted in that form.

Half of the classes will be conducted in that form.

More than $75 \%$ of the classes will be conducted in that form.

The gender has been included in the survey because female students are more satisfied with tutors' contribution to the education of students than male students (GONZÁLEZ-GÓMEZ, 2012; LU, 2010). 72\% of respondents were satisfied with e-learning mode while $28 \%$ of them were dissatisfied.

Issues connected with the new approach to the education, that is e-learning, showed the following advantages and disadvantages of this form of education:

- flexibility of work,

- independence of learning any time,

- raising awareness owing to added materials, films and papers,

- self-management time,

- self-discipline.
Disadvantages of e-learning as result of research are following:

- technical problems with Moodle platform,

- the absence of a student on the training introductory generates subsequent problems in the service platform by him, for example: no password to access the subject, no knowledge about the fact that following lessons are in e-learning form,

- lack face to face contact with ateacher,

- aversion to reading material,

- problems with self-discipline,

- problems with self-management time.

\section{Summary}

E-learning, until recently known as the future of education, is becoming the present reality. It has brought a number of new opportunities.

Based on the researcher conducted, it was stated that e-learning is an innovation in Polish education but, as many authors claim, e-learning can be as effective as conventional in-class face-to-face teaching and learning methods if the techniques are appropriate for teaching goals with a well-organized student-teacher interaction(OZTEKIN A., DELEN D., TURKYILMAA A., \&ZAIM S., 2013).

The development of the Internet and its applications has determined an increase of the role of computerbased instruments in the learning process. The use of Internet for teaching and learning is becoming a natural extension of a classroom. The modernization of education suggests that students donot only have to acquire skills and habits to work with the growing amount of information and more sophisticated information streams, but also have to possess an ability to obtain new knowledge, to build independently an overall cognitive process in the surrounding IT environment (SHOPOVA T. 2014, HOOPER AND RIEBER, 1999, CASTANEDA AND SOTO, 2010).

Several countries can benefit fromthe support of elearning to enhance their education and their research and to go towards learning.

It was also stated that for foreign students who decide to enrol to the Czestochowa University of Technology within the Erasmus programme, Moodle is a solution that can be considered their future tool for education. 


\section{Literature}

1. Shopova T. Digital Literacy of Students and Its Improvement at the University, Journal on Efficiency and Responsibility in Education and Science, Vol. 7, No. 2, (pp. 26-32), online ISSN 1803-1617, printed ISSN 1803-1617, doi: 10.7160/eriesj.2014.070201, 2014.

2. ARdid M., Gómez-TEJEdor J. A., MESEguerDueÑAS, J. M., RIERA, J., \&VIDAURRE A. Online exams for blended assessment. Study of different application methodologies. Computers \& Education, 81, 296$303,2015$.

3. Wu J. H., Tennyson R. D., Hsia T. L. \&LiaoY. W. Analysis of e-learning innovation and core capability using a hypercube model. Computers in Human Behavior, 24, 1851-1866, 2008.

4. PAechter M., Maier M. \& B. Online or face-to-face? Students' experiences and preferences in e-learning. Internet and Higher Education. 13(4), 292-297, 2010.

5. LIAW S. S. Investigating students' perceived satisfaction, behavioral intention, and effectiveness of elearning: A case study of the Blackboard system. Computers \& Education, 51, 864-873, 2008.

6. Otter R. R., Seipel S., Graeff T., Boraiko B. A., Gray C., Petersen J., SAdler K. Comparing student and faculty perceptions of online and traditional courses. Internet and Higher Education, 19, 27-35, 2013.

7. GonZÁlez-Gómez F., GuARdiola J. \& MARTíN RODRÍGUEZ Ó..Gender differences in e-learning satisfaction. Computers\&Education, 58(1), pp. 283-290, 2012.

8. OzTeKin A., Delen D., TurkyilmaA A., \&ZAim S., A machine learning-based usability evaluation method for e-learning systems, Decision Support Systems, 56 (2013), pp. 63-73, 2013.

9. MULDER K. F. Strategic competences for concrete action towards sustainability: An oxymoron? Engineering education for a sustainable future. Renewable and Sustainable Energy Reviews, 2016.

10. Bedrule - GrigorutaM.V., Rusu M.L. Considerations about e-learning tools for adult educations, Procedia - Social and Behavioral Sciences, Volume 142, pp. $749-754,2014$.

11. HOOPER AND RIEBER, Teaching, instruction, and technology. In A. C. Ornstein \& L. S. Behar-Horenstein
(Eds.), Contemporary Issue in Curriculum (2nd ed., pp. 252-264). Boston, MA: Allyn and Bacon., 1999

12. CASTANEDA AND SOTO, Building personal learning environments by using and mixing ICT tools in a professional way. Digital Education Review, 2010.

13. OproIU G.C. A Study about Using E-learning Platform (Moodle) in University Teaching Process, Procedia - Social and Behavioral Sciences 180, pp. $426-$ 432, 2014. 